\title{
El mercado de Atarazanas de Málaga del arquitecto Joaquín Rucoba
}

ORDIERES DÍEZ, Isabel

Ayuntamiento de Málaga, Málaga, 2017

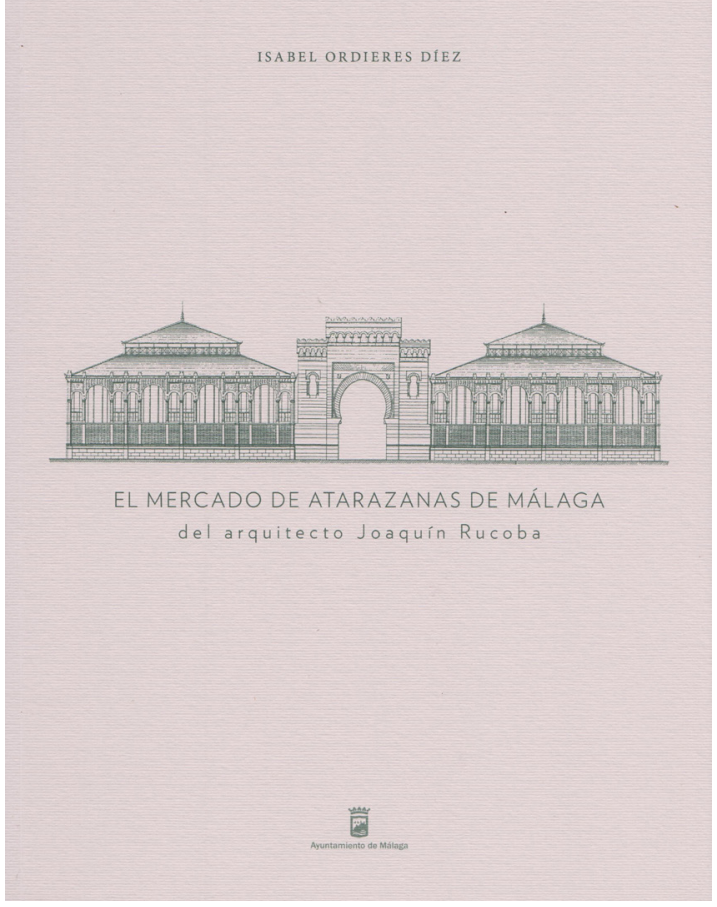

El presente libro constituye una notable aportación a la figura del arquitecto Joaquín Rucoba y Octavio de Toledo (18441919), muy representativo de la coyuntura arquitectónica de finales del siglo XIX y de la figura del arquitecto funcionario, en función de lo cual trabajó sucesivamente en Málaga y Bilbao.

De este personaje teníamos ya referencias previas gracias a esta misma autora, profesora de la Escuela de Arquitectura de la Universidad de Alcalá de Henares, en concreto una primera breve monografía que ayudó a descubrir a este profesional, llamado a conseguir considerable fortuna crítica con el tiempo.

En la introducción, la artífice del volumen, la doctora Isabel Ordieres, nos explica que la presente investigación, centrada en Málaga, tuvo su arranque en la memoria histórica que elaboró para la restauración del mercado de hierro de las Atarazanas, o, como se denominó en su tiempo, de Alfonso XII.
Rucoba llegó a Málaga muy joven, en 1870, cuando la ciudad estaba inmersa en una etapa de gran esplendor por su temprano despegue industrial, no muy conocido en el resto de España aún hoy. Esa industrialización terminaría desplazándose a Asturias y Vizcaya por diversas razones vinculadas a coyunturas adversas, siendo crucial la sustitución del carbón vegetal por el carbón mineral o hulla en la siderurgia.

En esta obra, la autora ha hecho el esfuerzo de ir encajando multitud de piezas sueltas de lo que fue la labor de Rucoba como arquitecto municipal. Ya nos advierte en la introducción de la pérdida de gran parte de los planos y proyectos por él dibujados, aunque recientemente se hayan conseguido recuperar copias desconocidas, concretamente del proyecto del mercado. A pesar de ello, el libro consigue destacar por su profusión de imágenes. A lo largo del texto, no solo se habla del complejo proceso de construcción del mercado de las Atarazanas, sino también de la impronta que desde el punto de vista de la modernización urbana de la ciudad significó.

Este edificio reunió en su día algunas especificidades que la autora resalta. Por un lado, el que fuera uno de los primeros proyectos metálicos diseñados íntegramente en nuestro país (el proyecto se firmaría en 1871), cuando otros contemporáneos madrileños, como el de la Cebada o el de los Mostenses, se debieron a ingenieros franceses, aunque la dirección de obra se llevara a cabo por arquitectos españoles.

Por otro lado, y esto quizás sea a nuestro juicio lo más significativo, este inmueble tuvo un pie forzado. Nos referimos a la exigencia impuesta desde la propia instancia municipal de que se integrara en el nuevo edificio el antiguo arco de la puerta de las Atarazanas, de etapa nazarí, sobre cuyo solar se iba a construir el mercado. Este monumental arco de herradura lo había conseguido salvar la Academia Provincial de Málaga, cuando se ordenó el derribo del edificio hispanomusulmán, obsoleto hacía ya siglos.

Esta circunstancia tan excepcional, y más si cabe en esos años iniciales de la salvaguardia del patrimonio arqui- 
tectónico, es lo que en parte da sentido a la investigación de Ordieres, especialista en arquitectura del siglo XIX y, sobre todo, en la historia de la restauración arquitectónica de esa etapa. En pocos casos como este se pueden ver unidos ambos aspectos de una manera tan peculiar y única. La autora desgrana todas las vicisitudes, los encuentros y desencuentros dentro del Consistorio y entre los intelectuales y profesionales coetáneos sobre cómo debían enfrentarse a un reto de esa naturaleza.

El edificio, desde un principio, se presentó ante la opinión pública como un símbolo del progreso económico, de la modernización que estaba viviendo la ciudad, pero terminaría convirtiéndose en un referente, para los historiadores y arqueólogos locales, de la recuperación y creciente respeto por un pasado musulmán propio, que se estaba empezando a sentir como seña de identidad.

Queda constancia en este estudio, aunque ya éramos conscientes por trabajos anteriores de investigadores malagueños, a los que se va aludiendo en el libro, de la pujante vida cultural de la ciudad en esas décadas, en gran parte promovida por la Academia Provincial.

La autora nos cuenta cómo todo ello va fraguándose hasta el resultado final, y lo recoge en un prolijo apéndice documental que consideramos un acierto, por lo que contribuye a profundizar en aquellos aspectos posibles que cada investigador particular pueda buscar en relación con esta historia.

Es interesante cómo se destaca en el libro el posicionamiento del gran erudito del momento dentro de la Real Academia de Bellas Artes de San Fernando, Pedro Madrazo. Gracias a los fondos de esta institución madrileña, la autora completa la coyuntura específica que rodeó la construcción del Mercado de las Atarazanas. En estos documentos Madrazo aparece temeroso, incluso desafiante, al desconfiar de que no se supiese intervenir adecuadamente en la preservación del arco de la puerta de las Atarazanas. En esta dirección, es muy significativa la correspondencia cruzada al respecto, que pone en evidencia una actitud un tanto centralista en la manera de entender los criterios de salvaguardia del patrimonio nacional.

Rucoba se decantó finalmente por la concinnitas, diseñando para las estructuras y las piezas de fundición industrial un ornamento basado en los modelos nazaritas, con el fin de enlazar lo nuevo con el antiguo arco árabe. Compartimos la afirmación de Ordieres de la influencia ejercida por Owen Jo- nes y sus estudios sobre la Alhambra, todavía muy cercanos en el tiempo, en el ánimo de Rucoba. En este sentido, recordemos la exposición sobre la relevancia de este autor inglés en la visión europea del monumento granadino, organizada no hace muchos años por el Museo de la Alhambra.

Como decíamos al principio de esta reseña, la oportunidad de este trabajo, creemos que radica en una doble vertiente, por cuanto se extiende también a la dilatada labor que Rucoba, como arquitecto municipal, desarrolló en Málaga. Desde esta instancia redactaría unas importantes ordenanzas municipales, reproducidas también en el apéndice documental de esta monografía junto con numerosos expedientes de tramitación de obras de reforma interior urbana. Ordieres ha hecho un considerable esfuerzo por ordenar y arrojar nueva luz sobre el protagonismo del arquitecto en reformas urbanas fundamentales no solo durante su etapa como arquitecto funcionario sino en otras obras de gran calado urbano, cuyo papel no quedó en el tiempo bien aclarado por su farragosa tramitación y compleja ejecución material, y que seguramente requerirán todavía mayores matizaciones futuras.

En efecto, la autora nos explica cómo muy superada en el tiempo su etapa de arquitecto municipal, cargo del que dimitiría a causa de desavenencias con la corporación municipal por problemas de competencias, la familia Larios le reclamó para culminar algunas obras que se habían ido dilatando más de lo deseable, caso de la calle homónima o el Parque.

El libro nos ofrece además una perspectiva global de toda la obra de Rucoba en Málaga y en otros puntos de la geografía española donde trabajó. Tras abandonar esta ciudad, logró en 1883 la plaza de arquitecto municipal de Bilbao, enclave inmerso en un espectacular proceso de crecimiento y transformación. Allí también elaboró unas nuevas ordenanzas de construcción que entraron en vigor en 1886.

Del resto de su producción destaca el original frontón de pelota vasca, Beti-Jai de Madrid con una singular estructura también metálica. Este edificio ha sido recientemente restaurado y salvado de lo que parecía una desaparición segura. En su última etapa profesional construiría en calidad de arquitecto diocesano algunos edificios singulares en Cantabria, su tierra natal, donde decidió regresar para terminar allí sus días.

Maite Paliza Monduate Universidad de Salamanca 